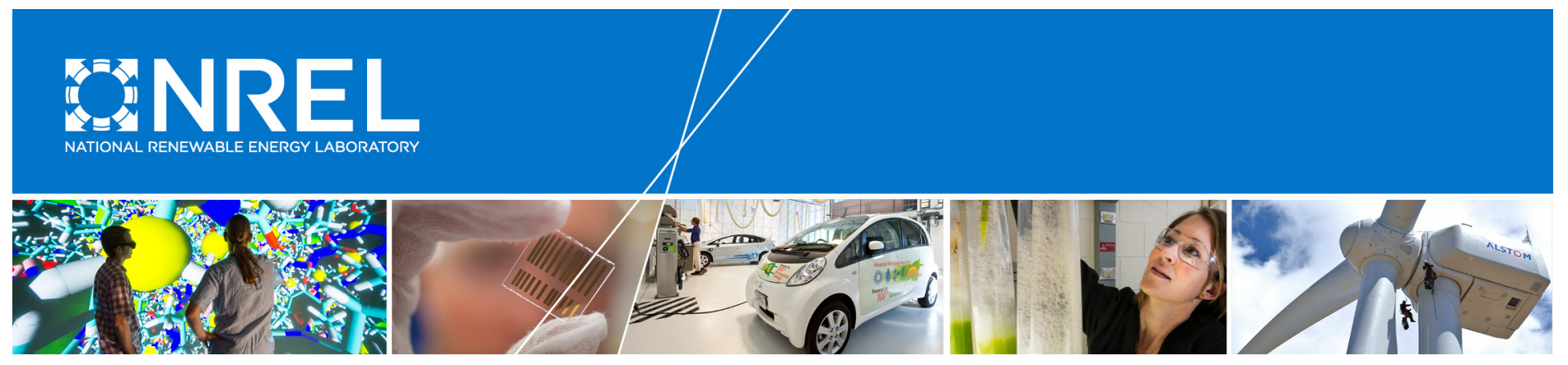

\title{
High Octane Fuel: Terminal Backgrounder
}

Kristi Moriarty

National Renewable Energy Laboratory

NREL is a national laboratory of the U.S. Department of Energy Office of Energy Efficiency \& Renewable Energy Operated by the Alliance for Sustainable Energy, LLC

This report is available at no cost from the National Renewable Energy Laboratory (NREL) at www.nrel.gov/publications.

Technical Report

NREL/TP-5400-65760

February 2016

Contract No. DE-AC36-08GO28308 


\section{High Octane Fuel: Terminal Backgrounder}

Kristi Moriarty

National Renewable Energy Laboratory

Prepared under Task No. BB14.4620
NREL is a national laboratory of the U.S. Department of Energy Office of Energy Efficiency \& Renewable Energy Operated by the Alliance for Sustainable Energy, LLC

This report is available at no cost from the National Renewable Energy Laboratory (NREL) at www.nrel.gov/publications.

\section{Technical Report}

NREL/TP-5400-65760

February 2016

Contract No. DE-AC36-08GO28308

Contract No. DE-AC36-08G028308
National Renewable Energy Laboratory 15013 Denver West Parkway

303-275-3000 • www.nrel.gov 


\section{NOTICE}

This report was prepared as an account of work sponsored by an agency of the United States government. Neither the United States government nor any agency thereof, nor any of their employees, makes any warranty, express or implied, or assumes any legal liability or responsibility for the accuracy, completeness, or usefulness of any information, apparatus, product, or process disclosed, or represents that its use would not infringe privately owned rights. Reference herein to any specific commercial product, process, or service by trade name, trademark, manufacturer, or otherwise does not necessarily constitute or imply its endorsement, recommendation, or favoring by the United States government or any agency thereof. The views and opinions of authors expressed herein do not necessarily state or reflect those of the United States government or any agency thereof.

This report is available at no cost from the National Renewable Energy Laboratory (NREL) at www.nrel.gov/publications.

Available electronically at SciTech Connect http:/www.osti.gov/scitech

Available for a processing fee to U.S. Department of Energy and its contractors, in paper, from:

U.S. Department of Energy

Office of Scientific and Technical Information

P.O. Box 62

Oak Ridge, TN 37831-0062

OSTI http://www.osti.gov

Phone: 865.576.8401

Fax: 865.576.5728

Email: reports@osti.gov

Available for sale to the public, in paper, from:

U.S. Department of Commerce

National Technical Information Service

5301 Shawnee Road

Alexandria, VA 22312

NTIS http://www.ntis.gov

Phone: 800.553 .6847 or 703.605 .6000

Fax: 703.605.6900

Email: orders@ntis.gov 


\section{Acknowledgments}

This report was sponsored by Department of Energy's Bioenergy Technologies Office. 


\section{List of Acronyms}

API

CFR

E10

EPA

HOF

OPIS
American Petroleum Institute

Code of Federal Regulations

$10 \%$ ethanol; $90 \%$ gasoline

U.S. Environmental Protection Agency

high-octane fuel

Oil Price Information Service 


\section{Executive Summary}

The Bioenergy Technologies Office of the U.S. Department of Energy Office of Energy Efficiency and Renewable Energy sponsored a scoping study to assess the potential of ethanolbased high octane fuel (HOF) to reduce energy consumption and greenhouse gas emissions. ${ }^{1}$ HOF blends used in an engine designed for higher octane have the potential to increase vehicle energy efficiency through improved knock suppression. When the high-octane blend is made with $25 \%-40 \%$ ethanol by volume, this energy efficiency improvement is potentially sufficient to offset the reduced vehicle range often associated with the decreased volumetric energy density of ethanol. With this scenario in mind, the purpose of this study is to assess the ability of the fuel supply chain to accommodate more ethanol at fuel terminals. Fuel terminals are midstream in the transportation fuel supply chain and serve to store and distribute fuels to end users. The study does not cover the impacts on ethanol and gasoline markets supply and demand or other parts of the fuel supply chain.

This report summarizes terminal equipment, operations, statistics, and regulations. It serves largely to provide a background on how terminals operate and opportunities for handling greater volumes of ethanol. As a part of this study, the National Renewable Energy Laboratory interviewed companies who own terminals and visited several terminals to gain insight into their operations, how ethanol is handled, any issues with ethanol storage, and the potential for terminals to store more ethanol.

The Oil Price Information Service reports that there are 1,296 terminals storing transportation fuel nationwide. These terminals are constantly receiving, storing, and dispensing fuels. Over 1,200 of these terminals are either storing ethanol or are capable of storing it. Terminal equipment includes piping, valves, meters, pumps, truck and rail unloading skids, and tanks. Finished transportation fuels are dispensed to trucks for delivery to retail stations and other enduse customers. This is achieved by complex control systems that pull fuels from various tanksgasoline blendstock, ethanol, and additives - into a loading arm that delivers fuel into the truck.

Interviews with companies indicate that there are minimal technical issues with storing and distributing more ethanol. However, there are several significant factors that could limit increased deployment of ethanol at terminals.

- The availability of land to add tanks and unloading equipment as well as land to accommodate increased truck traffic for ethanol deliveries.

- Permitting and regulatory processes to add tanks have become more time consuming and challenging in recent years.

- There are few existing tanks that are not already in use.

- It will be necessary to re-configure the existing loading racks and bay to accommodate additional equipment to fill trucks.

\footnotetext{
${ }^{1}$ More information on the HOF project as well as links to related reports are available on the Bioenergy Knowledge Discovery Framework: Accessed January 18, 2016: https://bioenergykdf.net/hof
} 
- A significant amount of capacity at terminals is leased to customers under long-term contracts to store specific fuels and volumes.

Terminals are capable of handling more ethanol if the market conditions indicate long-term demand sufficient to warrant building additional infrastructure. Terminal companies indicate that most of their tanks are in use; therefore, accommodating ethanol at a volume of $25 \%$ to $40 \%$ will likely require installation of new tanks and other equipment. Some terminal locations may experience land constraints to accommodate additional infrastructure and increased truck traffic for fuel deliveries. There are potential hurdles upstream to deliver more ethanol by rail. Further analysis is needed to determine the availability of rail cars and ability of transmodal facilities to handle more ethanol. 


\section{Table of Contents}

List of Acronyms ............................................................................................................................ iv

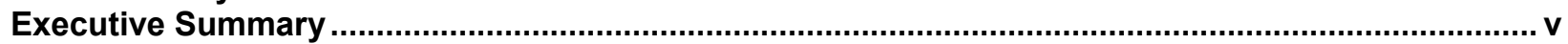

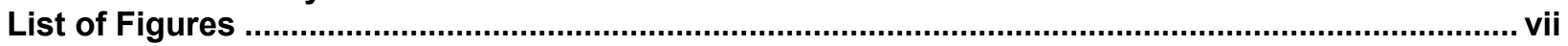

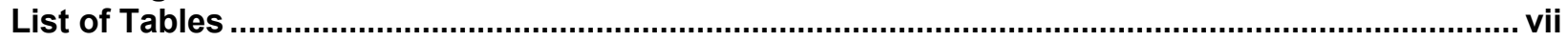

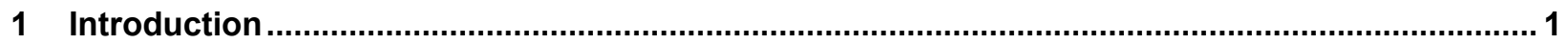

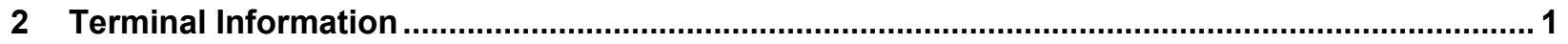

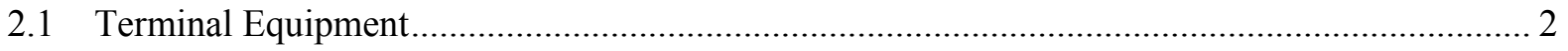

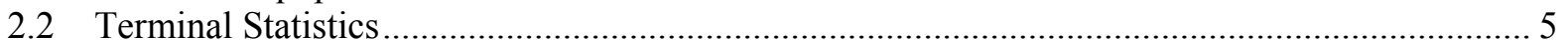

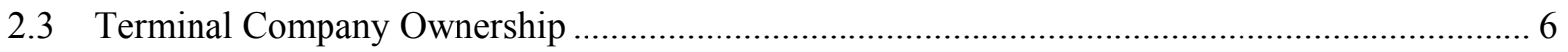

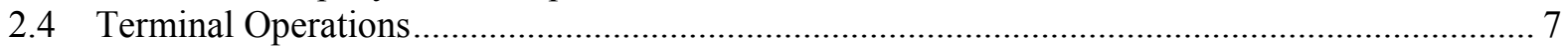

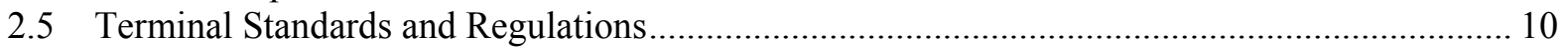

3 Ability to Store More Ethanol and Other New Fuels ............................................................ 11

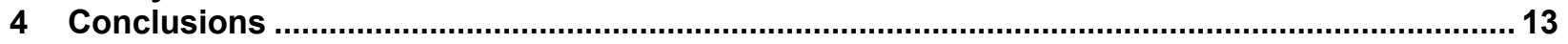

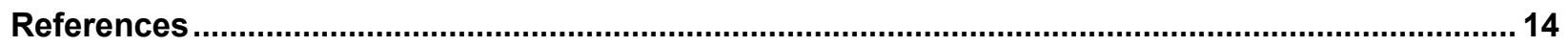

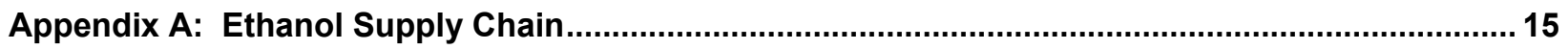

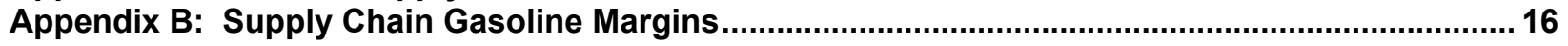

\section{List of Figures}

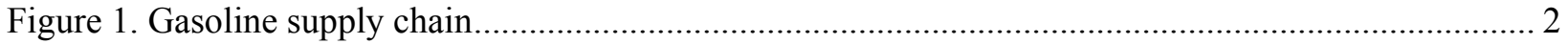

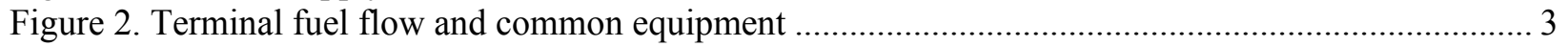

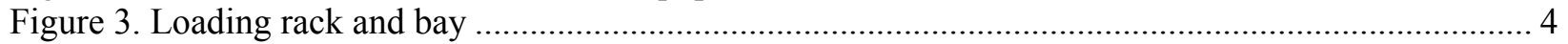

Figure 4. Tank farm with two ethanol tanks of different sizes in foreground......................................... 4

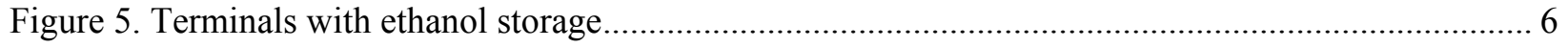

Figure 6. Terminal ownership and counts by company type ........................................................... 7

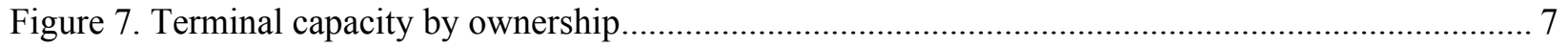

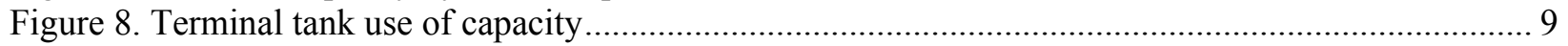

\section{List of Tables}

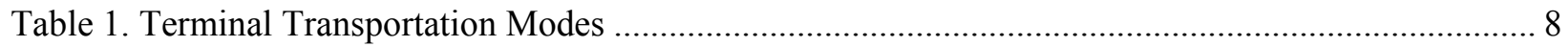




\section{Introduction}

The purpose of this report was to understand terminals and their ability to handle more ethanol should a high-octane fuel (HOF) of $25 \%$ to $40 \%$ ethanol enter the marketplace. Past fuels infrastructure studies funded by the U.S. Department of Energy focused on retail and fleet stations and their ability to store and dispense ethanol blends above E10 [10\% ethanol, 90\% gasoline] and other biofuels. These studies reviewed materials compatibility, equipment compatibility, the ability of existing equipment to accommodate higher biofuels blends, and general market conditions for retail stations. ${ }^{2}$ As the nation intends to deploy more biofuels, it is important to understand the impacts, opportunities, and barriers across the fuel supply chain. This study focuses solely on fuel terminals.

A literature review found that there are no existing documents with terminal data and information on the feasibility of adding new fuels. This paper provides background information with a focus on general terminal operations and statistics. The paper addresses how ethanol is received, stored, and dispensed to trucks that deliver fuel to end-users.

\section{Terminal Information}

Terminals are an important part of the transportation fuel supply chain, moving products to enduser markets. Their primary function is to store and distribute fuels. A typical terminal serving the on-road transportation fuels market would store regular and premium gasoline blendstock for oxygenate blending, diesel, denatured ethanol, and additives. These fuel types are stored in individual tanks. The number of tanks and the capacity for each fuel type are dependent on demand for the market the terminal serves. Terminals are constantly receiving and dispensing fuel - the mode of fuel receipt varies and may include pipeline, truck, barge/ship, and rail. A single terminal will serve many different customers through established contracts. Trucks arrive at a terminal and select fuels for their customer. Based on the fuels selected, products are pulled from various tanks to dispense a finished transportation fuel into the truck. Note that trucks can have multiple compartments and transport several fuels at one time. Figure 1 illustrates the gasoline fuel supply chain. Appendix A highlights the ethanol fuel supply chain specifically and Appendix B shows the gasoline supply chain and margins.

\footnotetext{
${ }^{2}$ Multiple materials and stations infrastructure reports are available on the Knowledge Discovery Framework's High Octane Fuel project page: https://bioenergykdf.net/hof
} 


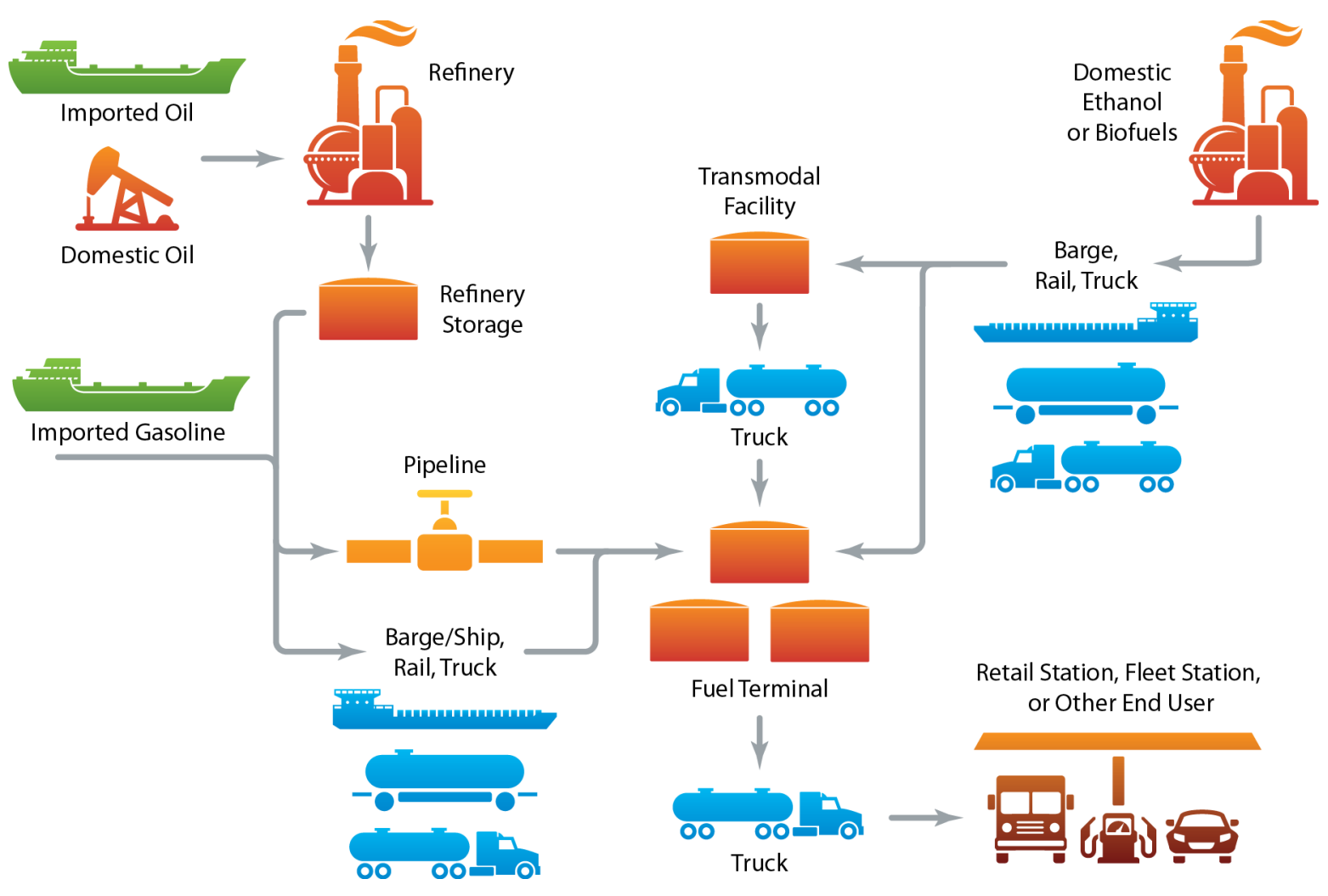

Figure 1. Gasoline supply chain

\subsection{Terminal Equipment}

A terminal includes many pieces of equipment designed to safely offload fuel from multiple transportation modes, store it, and load it into trucks for delivery to fuel stations. Figure 2 provides an overview of fuel flow and major equipment at a terminal. The most common equipment at terminals is pipes, valves, meters, and pumps. Pipes, usually made of carbon steel with welded joints, move fuel to storage tanks and deliver fuel to the loading rack. Valves are used throughout the system to control the flow of fuel. Meters measure and control the flow rate of fuel to ensure an accurate blend, and pumps move fuel throughout the terminal.

Trucks are loaded with finished fuel products at the loading rack - a sheltered area with multiple bays (Figure 3 ). Loading rack equipment includes loading arms that connect to the truck to deliver fuel, vapor recovery that is either burned off or collected to re-capture fuel products, a grounding line, a fire suppression system, and a computerized system for truckers to select fuels to be loaded.

Fuel storage tanks, called tank farms, are typically large and almost always above-ground (Figure 4). Tanks are usually made of mild steel and are erected onsite using American Petroleum Institute (API) standards. These large tanks have floating roofs that sit on the surface of the fuel and rise and fall as fuel is added and removed. The roofs serve as a method of controlling vapors. Diesel, or in some instances gasoline, tanks would have an external floating roof, so there is no permanent fixed roof. Ethanol is always stored in a closed, floating-roof tank due to its affinity for water. Small tanks with capacities below 1,190 barrels are generally 
purchased from a manufacturer and are UL listed under UL 142, Standard for Safety for Steel Aboveground Tanks for Flammable and Combustible Liquids. Tanks are equipped with pressure vacuum vents, emergency vents, shut-off valves, emergency valves, drain valves, a gauge, a grounding system, overfill prevention equipment, and leak detection equipment. Cathodic protection is used to prevent corrosion. Tanks are usually painted a light, reflective color to reduce evaporative losses and moisture condensation.

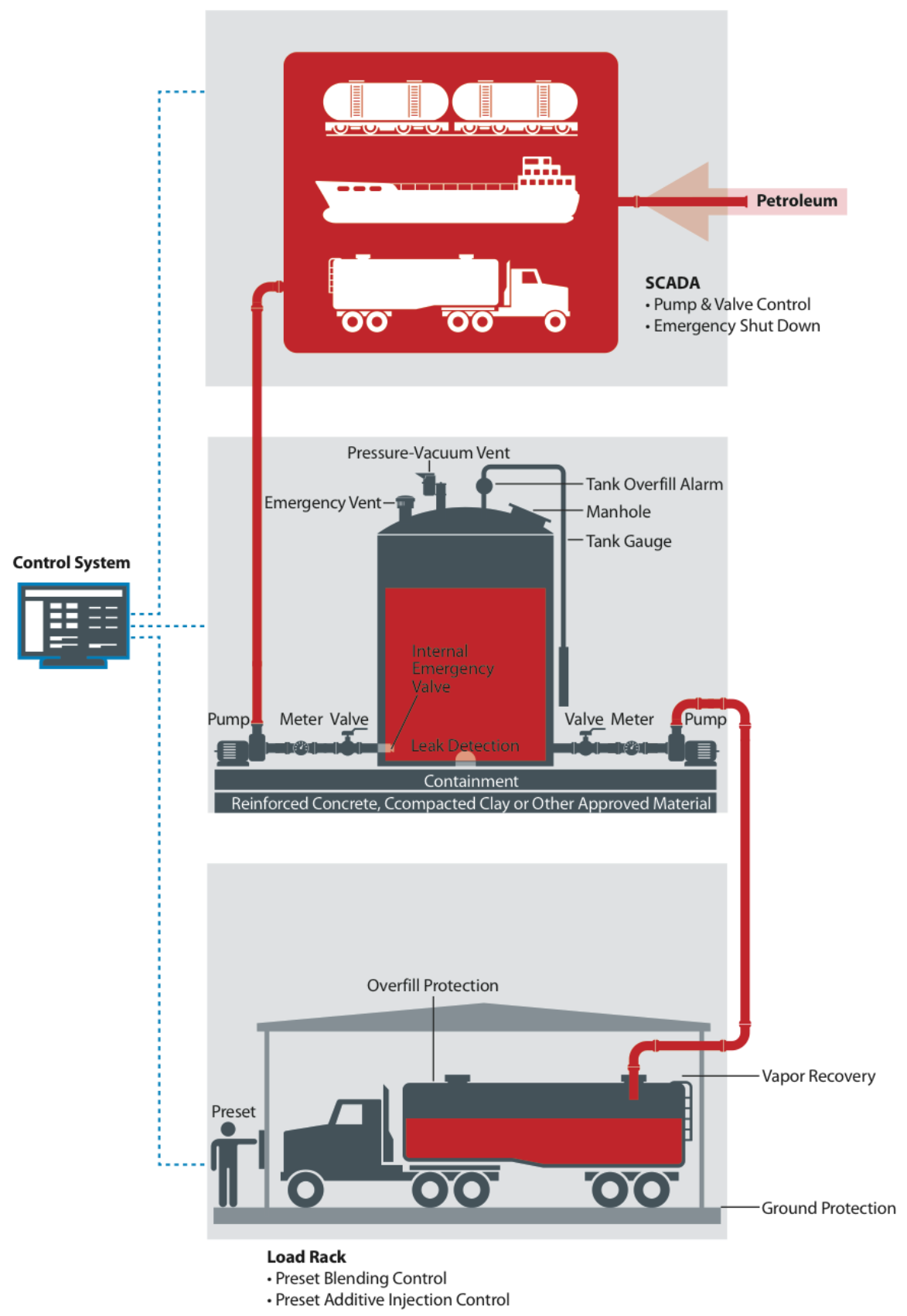

Figure 2. Terminal fuel flow and common equipment 

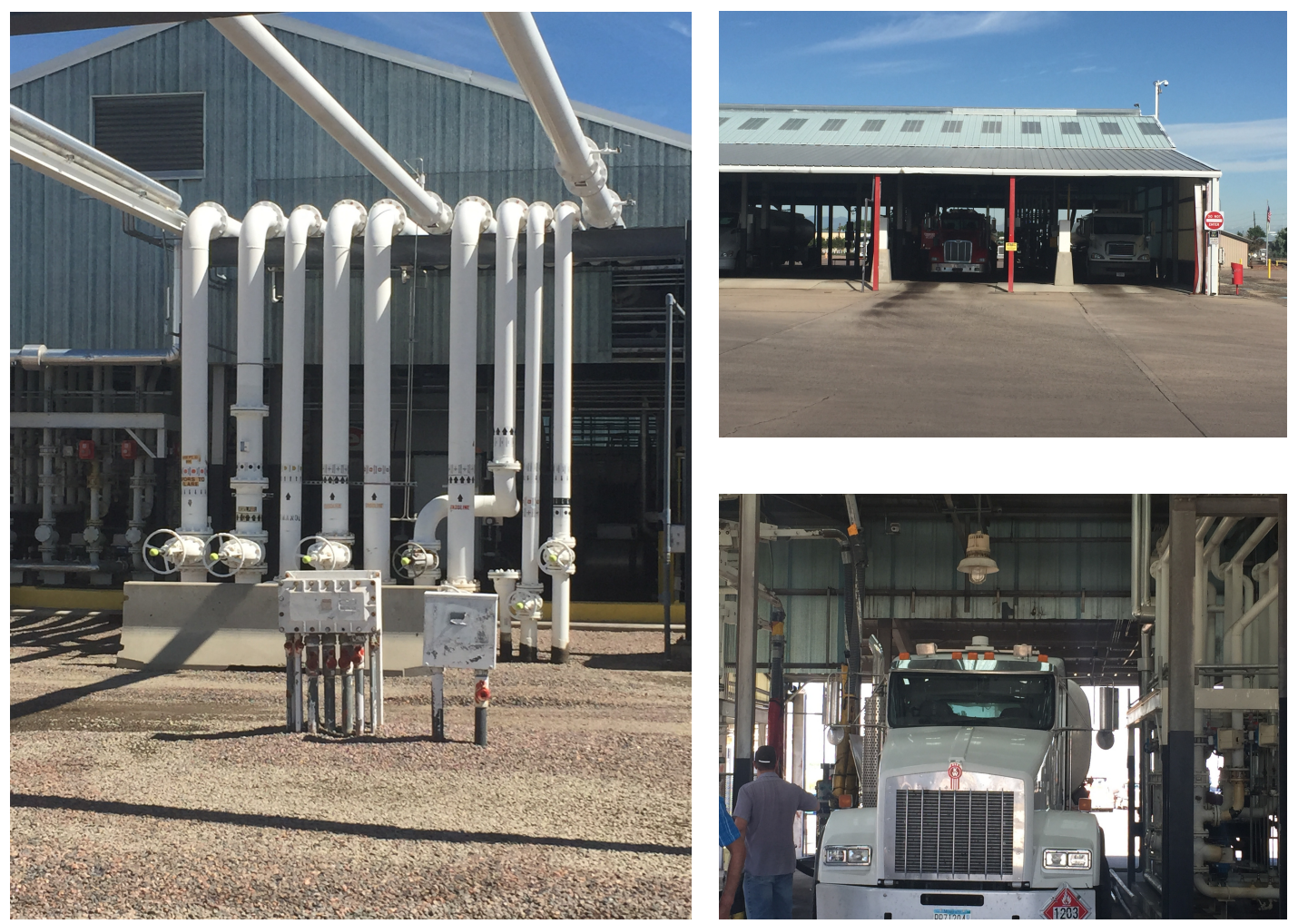

Figure 3. Loading rack and bay

Photos by Kristi Moriarty

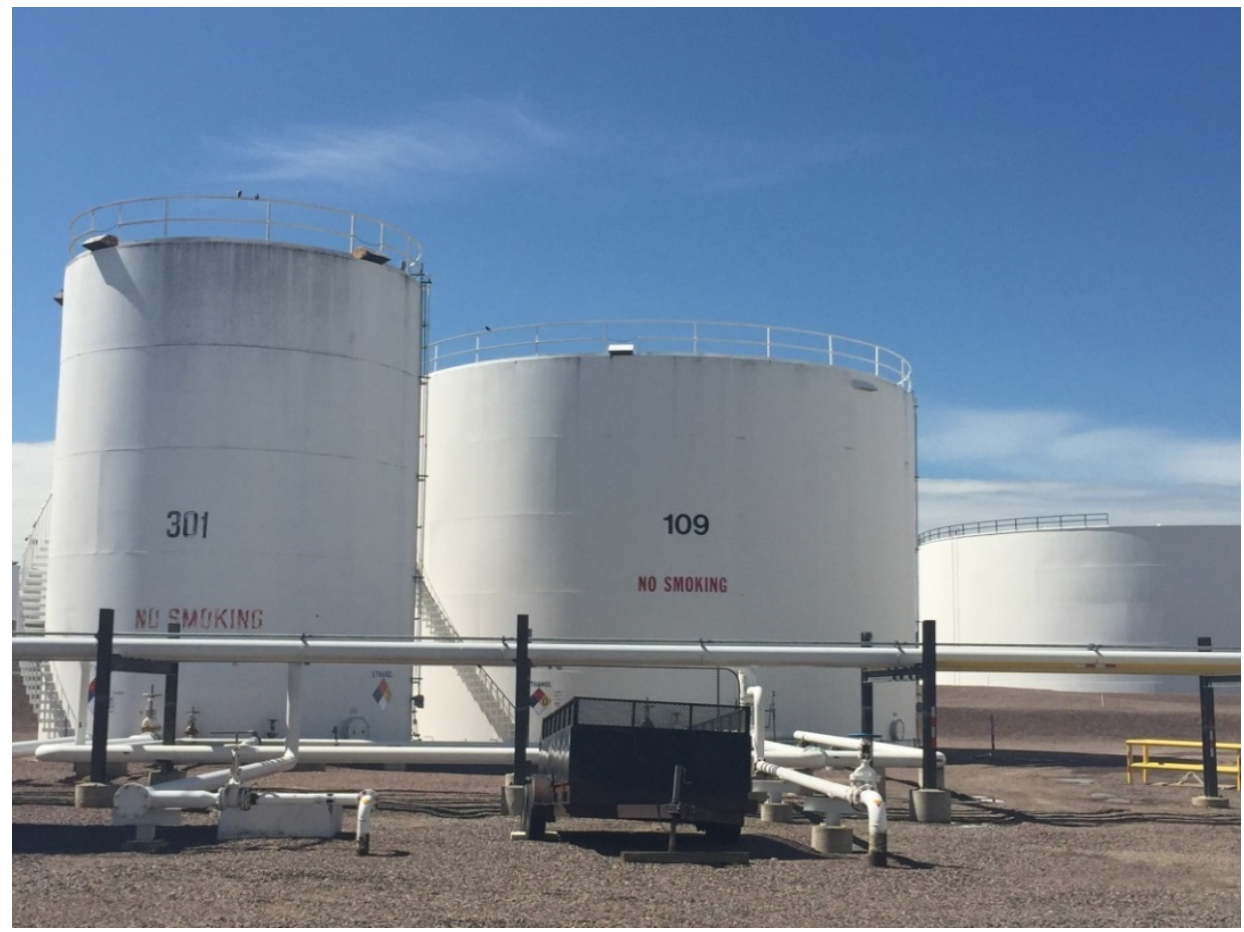

Figure 4. Tank farm with two ethanol tanks of different sizes in foreground

Photo by Kristi Moriarty 
Tanks are required by the U.S. Environmental Protection Agency (EPA) to have secondary containment made from compatible materials capable of holding the contents of the largest tank plus $10 \%$ to account for precipitation. Allowable secondary containment methods include berms, dikes, liners, vaults, and double-walled tanks. Sump pumps are used to remove precipitation from secondary containment systems.

Generally, gasoline and ethanol equipment are the same. Viton is the preferred elastomer material for gasoline and ethanol equipment. Some terminal operators line tanks and pipes prior to the storage of ethanol.

Terminals have complex computerized control systems that monitor all activities and the flow of fuel throughout the terminal. They have equipment for testing several parameters of fuel quality. A security fence is along the terminal perimeter, and most terminals require a badge to gain entry.

\subsection{Terminal Statistics}

Data in this section were consolidated from the Oil Price Information Service's (OPIS) Petroleum Terminal Encyclopedia. ${ }^{3}$ The data are both collected by OPIS and provided by companies with terminals. ${ }^{4}$ The data include location information, corporate information, terminal types, transportation methods for supply and outloading, pipelines used, berth data, total and individual storage capacity, types of fuels stored, number of tanks, and exchange throughput partners. Not all data are provided for all terminals, and OPIS does not guarantee the accuracy of the individual terminal data listings.

There are 1,450 terminals in the United States, and 1,296 report storing on-road transportation fuels (OPIS 2015). ${ }^{5}$ Some terminals store asphalt, crude oil, jet fuels, or other petroleum-based products not intended for on-road use. The number of tanks and capacity varies widely and is dependent on the number of commodities stored and the demand for the market served. The total storage capacity for all products stored at U.S. terminals is over 911 million barrels. Capacity at individual terminals ranges from a low of 714 barrels to a high of 48 million barrels per terminal. The nationwide average was approximately 770,000 barrels per terminal (OPIS 2015). The number of tanks per site also varies with a nationwide average of 19 (OPIS 2015). Terminals are often clustered in the same area, largely due to pipeline location and proximity to end users.

Over 1,200 terminals report that they either currently store or have the capacity to store ethanol in all 50 states (Figure 5) (OPIS 2015). ${ }^{6}$ A total of 363 terminals reported ethanol capacity with a

\footnotetext{
3 The U.S. Department of Energy defines bulk terminal as facility that stores petroleum products with a capacity of at least 50,000 barrels. Nearly all terminals in OPIS dataset meet this criteria.

http://www.eia.gov/tools/glossary/index.cfm?id=B

${ }^{4}$ OPIS/STALSBY Petroleum Terminal Encyclopedia is available for purchase:

http://www.opisnet.com/products/liquid-terminals-directory.aspx

${ }_{5}$ The Internal Revenue Service provides a list of active fuel terminals for excise tax purposes. API states that in July 2014 there were 1,335 active fuel terminals, and in July 2015 there were 1,303. This number is similar to OPIS data. http:/www.irs.gov/Businesses/Small-Businesses-\&-Self-Employed/Terminal-Control-Number-TCN-TerminalLocations-Directory

${ }^{6}$ The data state that all these terminals have stored ethanol; however, they may not have ethanol at all times.
} 
nationwide average of 12,867 barrels; however, there was great variation at terminals from a low at 238 barrels to a high of over 490,000 barrels (OPIS 2015).

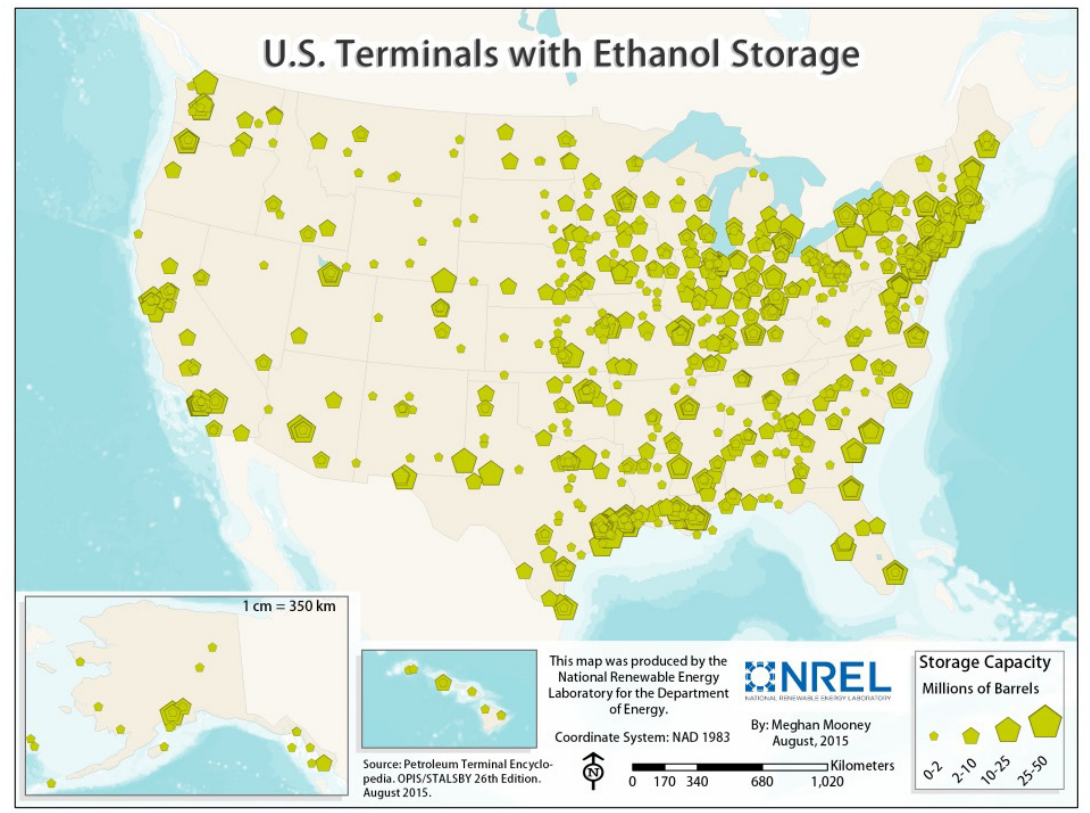

Figure 5. Terminals with ethanol storage

\subsection{Terminal Company Ownership}

There are several types of companies that own terminals. The National Renewable Energy Laboratory classified these companies based on OPIS data to gain insight into ownership. Figure 6 highlights the number of companies and terminals in each category, and Figure 7 illustrates capacity by category.

- Oil: Vertically integrated companies that explore and drill for oil and refine it. These companies may also own pipelines. Chevron accounts for more than half of the capacity in this category.

- Pipeline: Companies that own pipelines and lease storage space to customers at their terminals. Buckeye Partners, Kinder Morgan, and Magellan account for over $70 \%$ of terminals and $65 \%$ of the capacity in this category.

- Refinery: Companies that own refineries and terminals. These companies may also own pipelines. The top five companies account for $65 \%$ of both terminals and capacity and include Marathon Petroleum, Motiva (a joint venture between Shell Oil Company and Saudi Aramco), Phillips 66, and Tesoro.

- Terminal: Companies that own one or more terminals, but do not own pipelines or refineries. The majority of companies are in this category, and there is not consolidation of ownership as nearly half of the companies own a single terminal. TransMontaigne is a leader in this category with 50 terminals. Also of interest is Blendstar, an organization with eight terminals in the Midwest and South, which specializes in supplying renewable fuels. 
- Other: Companies with terminals that do not fit in other categories, including primarily asphalt, aviation, marine, and propane companies that store some on-road transportation fuels. This category also includes ethanol and biodiesel companies that own terminals.

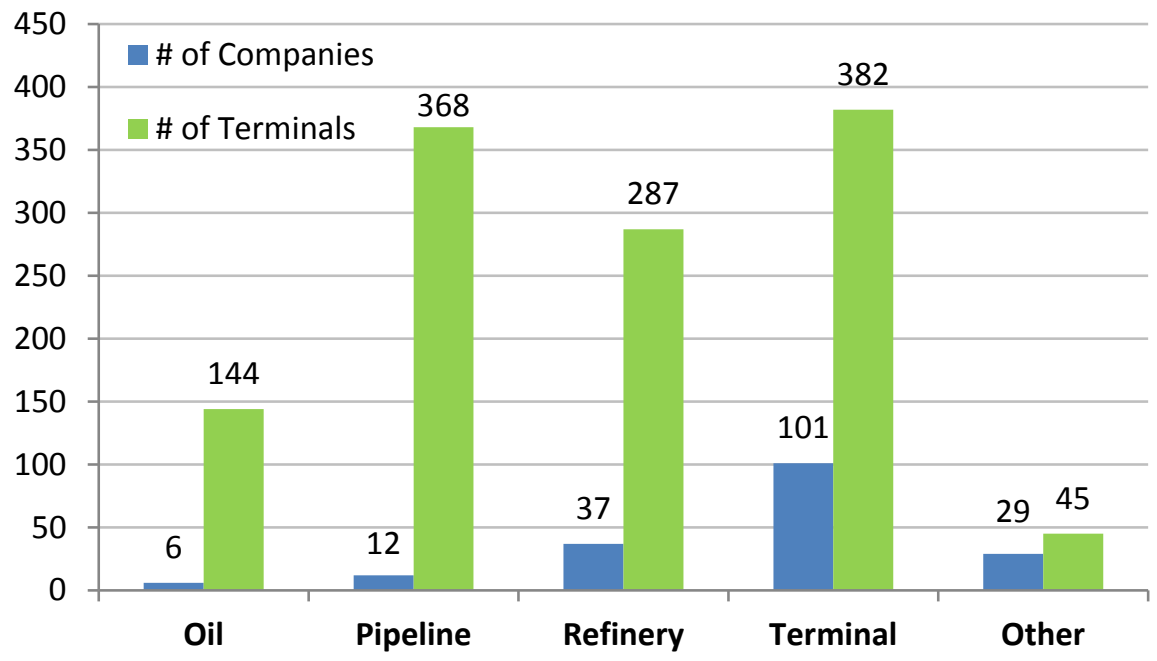

Figure 6. Terminal ownership and counts by company type

Source: The National Renewable Energy Laboratory classified companies based on OPIS data (OPIS 2015).

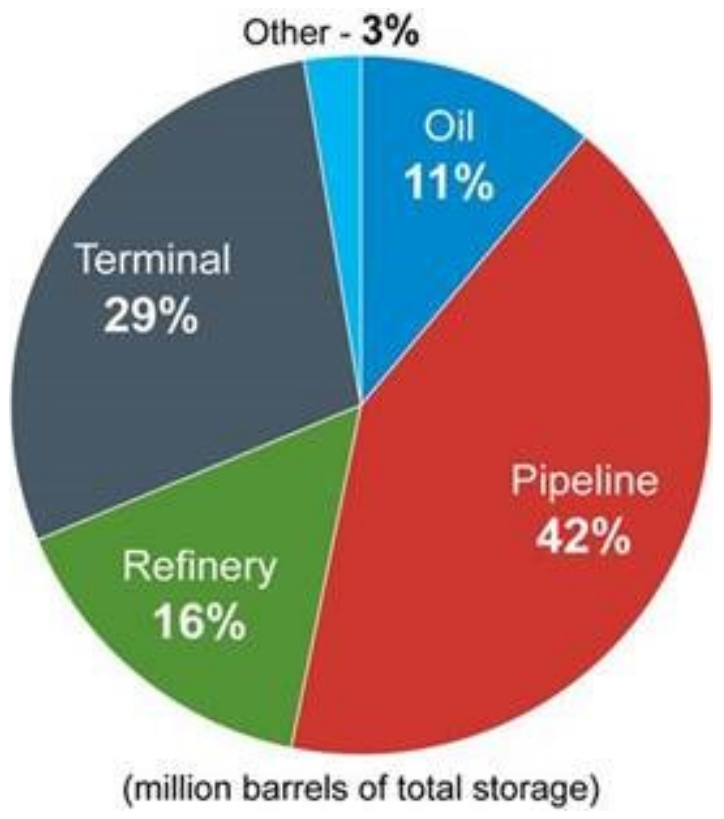

Figure 7. Terminal capacity by ownership

Source: The National Renewable Energy Laboratory classified companies based on OPIS data (OPIS 2015).

\subsection{Terminal Operations}

Terminals receive fuel by several transportation modes. Table 1 highlights that the majority of terminals can receive fuel by pipeline or truck. However, these data report on methods of receiving and outloading fuels; thus, there is an expectation that nearly all terminals could outload fuel by truck because the purpose of a terminal is to blend final fuel products for delivery 
to end users, usually retail stations. The assumption for this discrepancy is that some of the data were incorrectly reported. While ethanol is typically shipped by unit train, few terminals are equipped to receive unit trains. ${ }^{7}$ Companies with terminals interviewed for this report stated that it is rare to receive fuels by train, especially with the constraints affecting the availability of hazardous-fuel rail cars due to both new regulations and increased use of rail infrastructure to move crude oil.

Table 1. Terminal Transportation Modes

\begin{tabular}{|l|c|}
\hline Transport & Percent \\
\hline Barge & 36.5 \\
\hline Pipeline & 71.3 \\
\hline Rail & 22.0 \\
\hline Sea & 14.7 \\
\hline Truck & 88.4 \\
\hline
\end{tabular}

Source: OPIS (2015), based on 1,196 terminals reporting transportation modes.

The majority of ethanol is delivered by rail to trans-modal facilities and then trucked to terminals. Some trans-modal facilities deliver fuel to a terminal by a short pipeline. Terminals located in areas of ethanol production may receive fuel directly from an ethanol plant. Minimal ethanol is delivered by barge to terminals on waterways, primarily in the South and Northeast. Delivery of ethanol generally requires staff onsite because it is received by truck. Terminal companies reported ethanol and other fuels delivered by truck lack the flexibility for off-loading of petroleum fuels received by pipeline. Rail and truck deliveries are more likely to be impacted by weather events than pipelines. Fuel is constantly checked for quality as it is received and supplied, and many terminals test fuel quality of ethanol prior to off-loading the truck. The total time for receiving and off-loading ethanol into a storage tank is approximately 30 minutes.

Terminals often tie into a pipeline through a single pipe, and a series of valves and meters controls the flow of products from the pipeline to specific storage tanks for each fuel type. All fuels received by truck or barge/ship are off-loaded through pipes to the storage tanks. Tanks are constantly receiving and dispensing fuel, although some terminals do not fill tanks and dispense to trucks at the same time.

Tanks are not filled to their full storage capacity - they have a working capacity that is anywhere from $80 \%$ to $95 \%$ of the storage tank capacity depending on company practices (Figure 8 ). This allows for a contingency space providing a buffer between the stored fuel and the tank top/roof to reduce the risk of fuel spilling out through vents and damaging the internal floating roof.

\footnotetext{
${ }^{7}$ Unit trains are typically 110 cars carrying a single commodity and receive a better rate than single car shipments.
} 


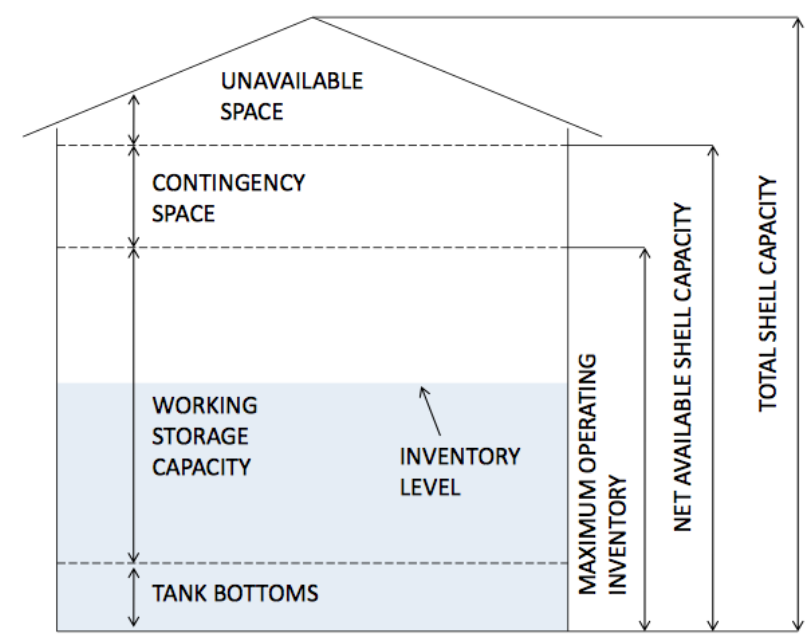

Figure 8. Terminal tank use of capacity

Source: EIA Form 815 Monthly Bulk Terminal and Blender Report Instructions. http://www.eia.gov/survey/form/eia 815/instructions.pdf

Complex computerized systems control the flow of fuel throughout a terminal. The most common method of blending gasoline fuel components is ratio blending, also referred to as inline blending. Ratio blending consists of two meters - one controls the flow rate of gasoline, and one controls the flow rate of ethanol. To maximize the flow rates of meters, many terminals will start loading a small volume of approximately 50 gallons of either gasoline or ethanol prior to loading both fuels at the same time. An injection system is used to blend additives. This method ensures an accurate blend if dispensing is interrupted.

Another, less common method, is sequential blending, where a single meter is used and one fuel component is loaded at a time. If dispensing is interrupted, the blend will be inaccurate.

Terminals generally do not allow splash blending, i.e., loading gasoline and ethanol separately to the truck.

Terminals enter into agreements with their customers which could be convenience store chains, branded or unbranded independent stations, or marketing companies or fuel service providers that deliver fuel to a station or other end users. Customers agree to buy fuel types with minimum and maximum volumes - the maximum volume can be exceeded if the terminal approves additional sales to a customer. Customers leasing space at a terminal enter into long-term contracts to store specific fuel types and volumes.

Terminals do not own the refueling trucks that load at their facilities. These trucks may be owned by a convenience store chain, independent trucking company, marketing company, or other customers. Truckers receive training at each terminal, and their truck is tested to ensure vapor seals are working properly. Truckers must adhere to a list of rules set by each terminal location or risk being locked out for days or permanently based on the severity of the violation.

At most terminals, a trucker will swipe a user card to enter the facility, and at all terminals, the trucker will swipe a card or enter a code at the loading rack. At many terminals, the trucker will 
enter a customer code, which will limit the list of fuels available based on the agreement with that customer. As an example, a truck picking up fuel for a Shell-branded station would not be able to select Conoco-branded fuel. The trucker connects the ground line and vapor recovery hose to their truck. The trucker will then connect the loading arm(s) and select the fuel types and quantities to be dispensed. After the trucker selects and confirms the fuel type and quantities, the terminal control system will release fuel from several tanks that will be delivered to the loading rack, which blends the fuels in-line through a loading arm into the truck. For example, if a trucker selects regular gasoline, the terminal control system will pull fuel from three tanks: gasoline, ethanol, and additives to provide a final finished gasoline product meeting fuel quality and EPA specifications.

It takes 15 to 20 minutes to fully load a truck. Fuel delivery trucks typically haul 8,500 gallons; however, a truck's capacity may range from 3,000 gallons to 11,500 gallons. These trucks have several compartments to store and deliver different fuel types to various customers.

\subsection{Terminal Standards and Regulations}

This section covers many, but not all, regulations and standards that apply to terminals. It is not meant to be an exhaustive list as requirements may vary based on size, location, transportation modes, and other terminal parameters. Aboveground storage tanks are subject to federal, state, and local regulations.

Terminal companies design, build, and maintain tanks as recommended by API Standard 650, Welded Tanks for Oil Storage, which provides requirements for materials, design, fabrication, erection, and inspection of aboveground storage tanks. API Standard 653, Tank Inspection, Repair, Alteration, and Reconstruction, applies to tanks exceeding 50 feet tall or 30 feet wide. A key component of API Standard 653 is tank inspection. The standard recommends that the tank owner inspect monthly and that an independent, certified inspector perform an external inspection every 5 years and an internal tank inspection every 10 years. API Standard 2350, Overfill Protection for Storage Tanks in Petroleum Facilities, provides methods and equipment types to minimize risk of a release caused by an overfill event.

There are several federal codes that terminals must adhere to that fall under both EPA programs and Occupational Safety and Health Administration jurisdiction. Title 40 Code of Federal Regulations Part 112 (40 CFR 112) applies to terminals storing petroleum in tanks greater than 1,320 gallons. The code requires aboveground storage tanks to have a secondary containment area around the tank capable of holding $110 \%$ of the tank volume. Methods of containment include dikes, berms, liners, vaults, or double-walled tanks. A sump pump must be used for rain water collection in the containment area, which could be an issue with an ethanol release due to the fuels' affinity for water. Tanks out of service one year or more typically require monitoring or removal.

In most instances, a Spill Prevention Control \& Countermeasures Plan is required by 40 CFR 112 and is designed to prevent release of petroleum products to navigable waters. The plan would apply to terminals that store crude oil as well as gasoline blendstock, diesel, and other transportation fuels. Fuel terminals are also subject to regulations under the National Pollutant Discharge Elimination System to ensure that discharge of storm water does not contain any fuel 
products. The EPA stated that aboveground storage tank releases are caused by holes from corrosion, piping failures, spills/overfills, equipment failure, and human error (EPA 2010).

While not required by federal code, the following practices are recommended to minimize risk of a release that could contaminate water (EPA 2010). This includes corrosion protection, which is universally used on terminal tanks; pipes should either be double-walled, aboveground, or cathodically protected. Fuel-resistant coatings are recommended to be applied to floors, containment areas, and the sump pump pit.

Terminals are required to obtain an operating permit to ensure compliance with air emission requirements per Title $\mathrm{V}$ of the Clean Air Act. ${ }^{8}$ The permit is typically issued by state or local permitting authorities as allowed under 40 CFR Chapter 1 Subchapter C Parts 70 and 71. An addition of a tank would result in the need to update the permit.

CFR Title 40 Chapter 1 Subchapter C Part 63 Subpart BBB, National Emission Standards for Hazardous Air Pollutants for Source Category: Gasoline Distribution Bulk Terminals, Bulk Plants, and Pipeline Facilities, specify terminal emission limits and how to demonstrate compliance. The code also stipulates tank filling requirements, monthly leak inspection of all equipment, reporting requirements including number of tanks and capacity, and average monthly throughput. Terminals with an average throughput of 250,000 gallons per day must have a vapor collection system for their loading racks. Terminals must submit a Notification of Compliance Status and any leaks to both their EPA Regional Office and the delegated state authority.

The Occupational Safety and Health Administration oversees 29 CFR Subtitle B Chapter XVII Part 1910 Subpart A 1910.106, which regulates fuel terminals with a focus on requirements for equipment. 29 CFR Subtitle B Chapter XVII Part 1917 Subpart B has additional requirements for marine terminals.

Terminals are also subject to local regulations. Local authorities having jurisdiction refers to regulating organizations, office or individuals responsible for overseeing codes and standards. Examples of authorities having jurisdiction include local fire marshals, state energy and environment offices, air and water boards, and similar organizations or offices.

\section{Ability to Store More Ethanol and Other New Fuels}

Nearly all terminals store ethanol, and there are no technical barriers to store larger volumes. However, there are potential issues such as the availability of land for additional infrastructure as well as accommodating substantial increases in truck traffic to deliver ethanol. There will need to be a strong business case to justify the cost of adding additional infrastructure to accommodate an HOF of $25 \%$ to $40 \%$ volume ethanol. Terminals are designed to serve the current market and generally do not have excess tanks or capacity within existing tanks. ${ }^{9}$ Another potential constraint is that many terminals lease their storage tanks to customers under long-term contracts. Additionally, increased domestic crude oil production has resulted in some terminals

\footnotetext{
${ }^{8}$ The operating (also known as 70, or air) permit information is available at: http://www.epa.gov/oaqps001/permits/

9 The Department of Energy's Energy Information Agency tracks terminal working and net storage capacity: http://www.eia.gov/petroleum/storagecapacity/storagecapacity.pdf
} 
storing crude prior to it being shipped by pipeline. This further constrains the availability of storage space at terminals.

For E10, the business opportunity was clear as the introduction of the federal renewable fuel standard coincided with the discontinued use of a previous oxygenate, methyl tertiary butyl ether. ${ }^{10}$ E10 could be used in existing vehicles and station equipment. Terminals used existing tanks or built new tanks and infrastructure to accommodate ethanol for blending up to E10. Terminal companies interviewed for this report stated that they have few unused tanks and are not able to supply E15 to all their customers at this time because they do not have sufficient infrastructure to handle it, and the same is true for a high-octane ethanol blend. Therefore, the storage of more ethanol would typically require a new tank and the associated piping, valves, meters, pumps, and equipment to connect it with the loading rack. Space at the loading rack could be a limiting factor as well as land to add a new tank. Additionally, a terminal would need the ability to receive more ethanol by truck, which would require more truck-off loading equipment to accommodate increased truck traffic delivering ethanol.

An analysis of upstream activities would need to be conducted to determine how terminals would receive additional ethanol supplies. Currently, the majority of terminals receive ethanol by truck either from a transmodal facility that receives ethanol by rail or directly from ethanol plants. It would need to be determined if the transmodal facilities serving terminals could handle more ethanol and if existing ethanol plants could supply more fuel. Additionally, with increased domestic crude oil production, there is competition for rail cars capable of transporting hazardous fuels. Some crude oil is being temporarily stored at terminals as centers of oil production have shifted with new extraction technologies. These areas may not have pipelines to move products.

All terminal companies interviewed stated that it has become more challenging and costly compared to past years to expand infrastructure due to permitting issues and regulations. Equipment is aging, but it is difficult to upgrade or replace equipment while maintaining permits and normal operations. Another constraint is the availability of contractors to erect new tanks. As the economy has improved, terminals stated that there is a long wait for qualified contractors.

A company with terminals would want to evaluate the impact of adding additional tanks and associated equipment on its EPA operating permit. It would also need approval from its state office having jurisdiction. Costs to add a new tank and associated equipment are averaging $\$ 40$ $\$ 50$ per barrel of installed capacity, with some terminals stating costs could be as high as $\$ 80$ per barrel. Those costs are for installed equipment and do not cover the costs for regulatory compliance.

When asked about issues with ethanol storage, terminal companies reported that ethanol requires more maintenance and that there can be supply disruptions due to weather because ethanol is delivered most often by truck. Some companies stated that they reduce the risk of stress corrosion cracking that could occur with ethanol by lining tanks and pipes while others address it with more maintenance. Additional maintenance increases labor costs and typical activities

\footnotetext{
${ }^{10}$ Methyl tertiary butyl ether was a refinery product that was blended with gasoline. Due to water contamination, many states banned its use, and it was replaced with ethanol blended at a rate of $10 \%$.
} 
include replacing valves and sealing materials more often. Some companies with fewer terminals stated they had occasional issues with maintaining a consistent ethanol supply. They thought the supply issue was largely a result of the ethanol traveling by rail and then truck to the terminals as these same companies have not experienced supply issues with petroleum products delivered by pipeline.

Some terminal companies stated that they avoid switching fuel stored in a tank unless it is necessary. Terminals have installed new tanks to accommodate biodiesel, which is stored in smaller, heated tanks. Biodiesel infrastructure was added due to customer demand for the product. This indicates that if enough customers ask for a product, there is the potential for a terminal to add infrastructure. Terminal companies interviewed for this report stated they were obligated parties under the renewable fuel standard, and these organizations could consider renewable identification number market values and volume requirements as a motivation to increase ethanol storage.

\section{Conclusions}

Terminals are midstream in the transportation fuel supply chain and are capable of receiving, storing, and dispensing various fuel types. To accommodate an $\mathrm{HOF}$ with $25 \%$ to $40 \%$ volume ethanol, additional infrastructure will need to be added, including tanks and additional truck unloading equipment as well as modifications to the loading rack and bay. Also, there would be a significant increase in truck traffic delivering ethanol. There will need to be a strong business case to justify the costs to install additional infrastructure to accommodate more ethanol at terminals. A potential significant barrier is the availability of land to accommodate additional infrastructure and increased truck traffic delivering ethanol. Further analysis of upstream activities is needed to determine the availability of fuel rail cars and the ability of transmodal facilities to handle more ethanol. 


\section{References}

U.S. Environmental Protection Agency (EPA). 2010. "Managing Above Ground Storage Tanks to Prevent Contamination of Drinking Water." Source Water Protection Practices Bulletin. August 2010.

Oil Petroleum Information Service (OPIS). 2015. Petroleum Terminal Encyclopedia, A Comprehensive Guide to Bulk Liquid Storage Throughout North America. $26^{\text {th }}$ Edition.

OPIS/Stalsby. July 2015. Accessed August 10, 2015: http://www.opisnet.com/products/liquidterminals-directory.aspx 


\section{Appendix A: Ethanol Supply Chain}

\section{Ethanol Supply Chain and Transportation Patterns}

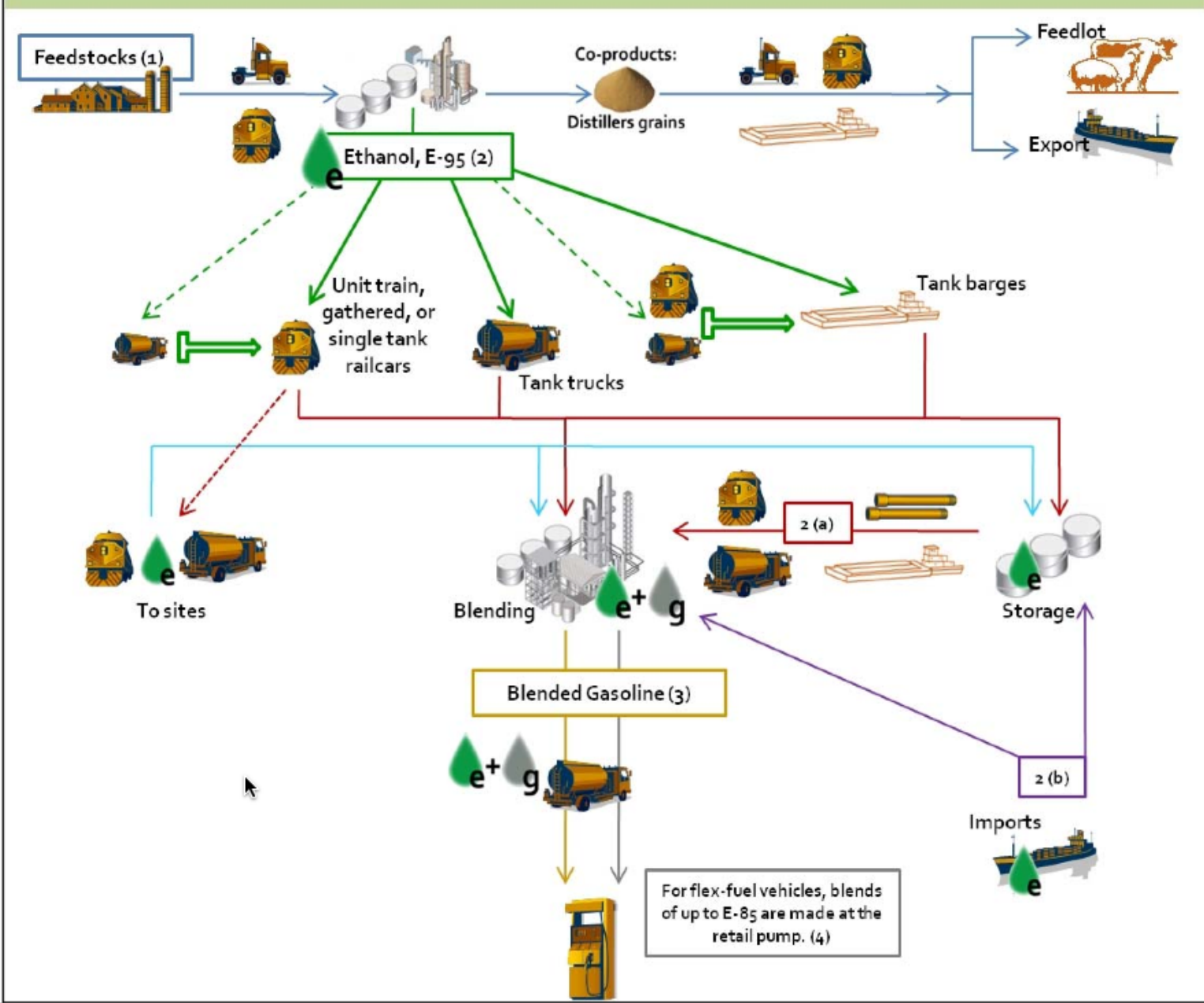

\section{Legend}

(1) Feedstocks via truck or rail to the biorefinery.

(2) Ethanol, which is denatured at the biorefinery, is shipped via truck, rail, or barge to a storage hub, petroleum or blending terminal, or rail-to-truck transloading (truck-to-rail, and truck-or rail-to-barge are intermediate moves.)

(a) Ethanol via truck, rail, barge, or pipeline from storage to blending terminal.

(b) Ethanol imports via ocean tanker vessel to storage or blending terminals.

(c) Ethanol via truck from rail-to-truck transloading to storage or blending.

(3) Ethanol and gasoline are blended at the meter and shipped via gasoline trucks from blending terminal to service stations.

(4) E85 blends are currently typically blended at the service stations serving E85, implying that ethanol is also delivered via truck to the service stations.

Source: Study of Rural Transportation Issues. The United States Department of Agriculture and the United States Department of Transportation. April 2010. Accessed July 28, 2015: http://ntl.bts.gov/lib/32000/32800/32855/STELPRDC5084108.pdf 


\section{Appendix B: Supply Chain Gasoline Margins}

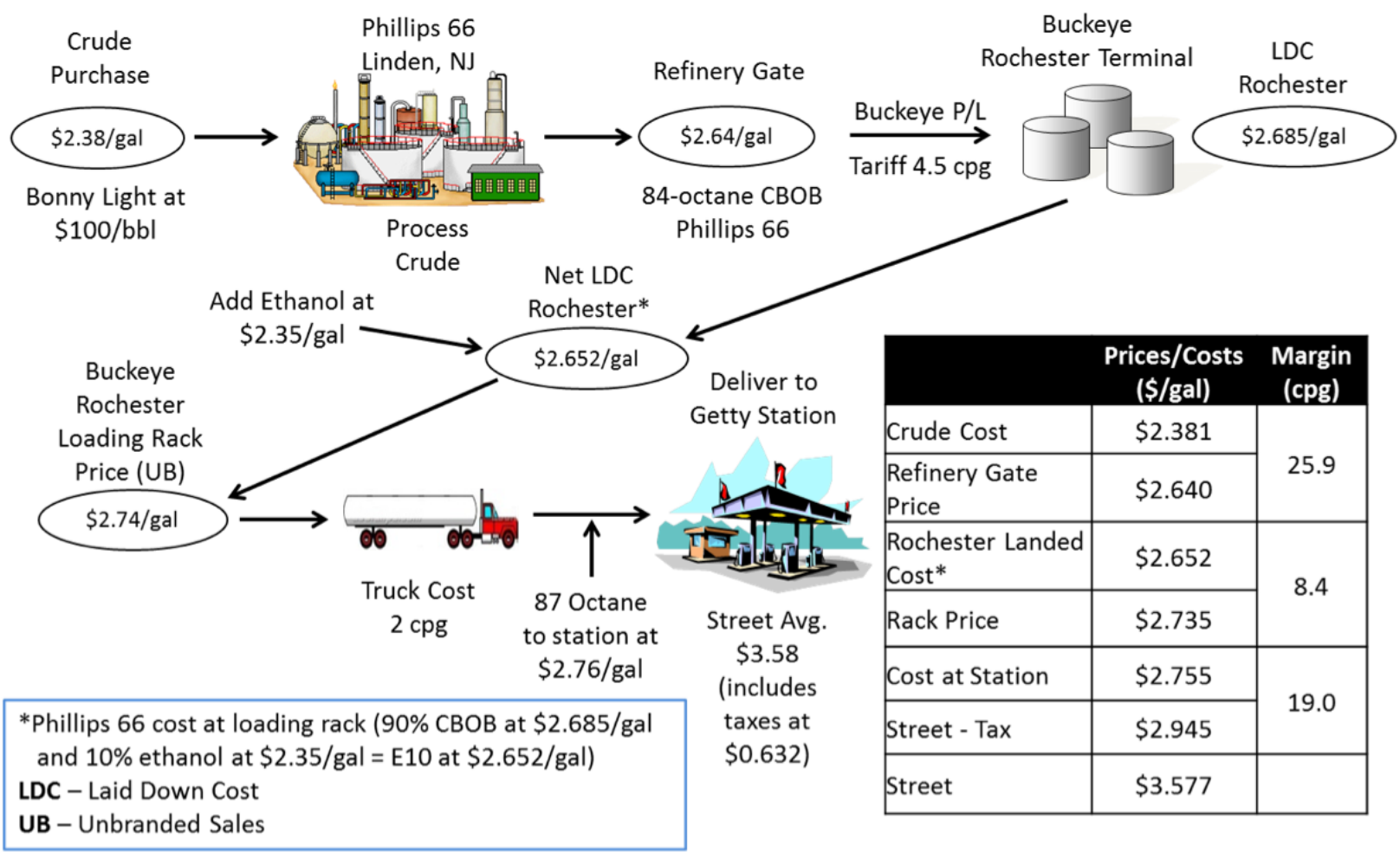

Source: New York State Transportation Infrastructure Study. ICF International. September 2012. Accessed July 28, 2015: http://www.nyserda.ny.gov/About/Publications/EA-Reports-and-Studies/Petroleum-Infrastructure-Studies 